\title{
Corrosion considerations in the design and operation of rock support systems
}

\author{
J.F. Dorion Niobec Inc., Canada \\ J. Hadjigeorgiou Lassonde Institute of Mining, University of Toronto, Canada
}

\begin{abstract}
The selection and design of rock support systems rarely takes into explicit consideration the susceptibility of the systems to corrosion. The loss in capacity associated with the corrosion of support systems can be a major safety and economic concern in underground hard rock mines. This paper reports on the influence of atmospheric, aqueous and microbiological corrosion on the performance of support systems in several, hard rock underground mines. In situ observations were complemented by laboratory investigations aiming to quantify the potential in loss of capacity of the installed support systems. A methodology is proposed to contribute to the selection and design of support systems in corrosive environments.
\end{abstract}

\section{Introduction}

An important issue in the design and implementation of ground control systems is the reduction in support capacity over time due to corrosion of the reinforcement and surface support units. This can have important ramifications in the ability of a support system to perform satisfactorily over its intended working life. This can have important economic and safety implications in the form of required rehabilitation and managing falls of ground (Figure 1).

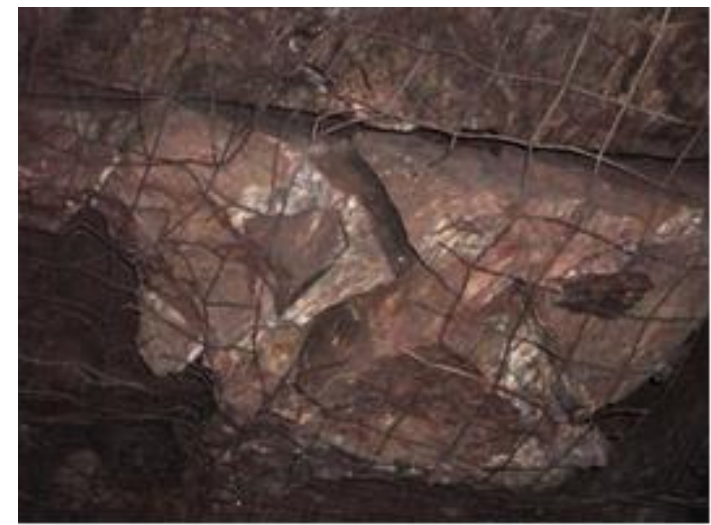

a)

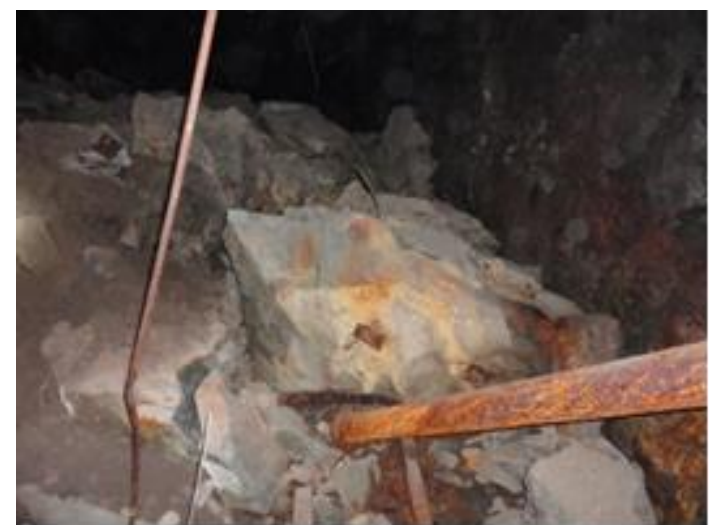

b)

\section{Figure 1 a) Mesh that failed as result of corrosion; b) Fall of ground attributed to corroded rock support}

A support system is considered to have failed when it no longer provides the support it was designed for. This can be brought about by failure of any element of the support, such as the rock bolt or mesh. The reduction in support capacity due to corrosion is currently not explicitly considered in the selection and design of an underground support system. Quite often, corrosivity is recognised as an issue during an investigation in the mechanisms and causes of failure that may have resulted in a fall of ground. Usually the emphasis is on fracture analysis aiming to identify the contribution of corrosion to a unit or system failure, Hadjigeorgiou et al. (2002). Fracture analysis focuses on the separation of a solid body into two or more parts under the action of stress that initiates and propagates the formation of cracks. A ductile fracture mechanism is characterised by considerable plastic deformation prior to and during propagation of a crack. 
In recognition of the importance of potential degradation of support, efforts have been made to develop classification systems to identify the corrosivity of mining environments, Robinson and Tyler (1999), Li and Lindblad (1999), Villaescusa et al. (2008). Currently, however, no classification systems linking corrosivity with ground support is widely accepted or implemented at mine sites. This can be attributed to a variety of reasons, such as site specific considerations, lack of substantial data to support the assertions of the classification systems and to back their recommendations, and possibly the lack of onsite expertise to implement these systems.

Based on in situ investigations and comprehensive laboratory experiments and testing, mine environments that contribute to the corrosion of support have been scrutinised. After collecting sufficient data for a comprehensive analysis, a framework was developed for the selection of appropriate support strategies for underground hard rock mines conditions susceptible to corrosion. Furthermore, this work provides recommendations that can be used to predict, with some degree of confidence, the operational life of a given support system. This can have important safety and economic repercussions for underground mines.

\section{In situ and laboratory investigations}

During the last five years, seven underground mines in Canada have participated in a long term study of the influence of corrosion on support performance. Participating mines were selected to obtain a wide range of different mining environment, geology, ore deposit, mining methods, etc. (Dorion and Hadjigeorgiou, 2008).

The visual corrosion system developed by Hadjigeorgiou et al. (2008) was used to qualify the impact of atmospheric and aqueous conditions on the support. This was complemented by a comprehensive testing program to monitor aqueous and atmospheric corrosion that involved direct measurements using corrosion coupons and analytical methods. An analysis of water samples is summarised in Table 1. Parameters recorded included: acidity or alkalinity; conductivity; solubility; salinity, etc.

Acidity or alkalinity, measured by a $\mathrm{pH}$ value defined as $-\log (\mathrm{H}+)$. Alkaline environments are characterised by high $\mathrm{pH}$ values with acidic solutions having low $\mathrm{pH}$ values. Acidic solutions are more corrosive and attack metals. Conductivity, the ability of a solution to transport current and is recorded in Siemens per meter $(\mathrm{S} / \mathrm{m})$ in S.I. units. As the conductivity of a solution increases, in most cases, so does the corrosion of immersed metals. Solubility is the quantity of an ion or gas in a solution. A high oxygen concentration in water results in a high rate of corrosion of iron. The corrosion rate of iron increases in the presence of higher dissolved oxygen. Salinity is reported as Total Dissolved Solids (TDS) and quantified as parts per thousand or parts per million. In general saline waters have a higher conductivity. The dissolved oxygen readings were calibrated to take into account the atmospheric pressure and water salinity and are reported in parts per million (ppm). Water sample temperature recorded in ${ }^{\circ} \mathrm{C}$. Typically corrosion rates increase as temperatures increase.

An appropriate interpretation of the results presented in Table 1 requires attention to the specificity of each mine. For example, Mine \#4 operates at greater depth and as a result of the geothermal gradient the ground water at two sampling sites is almost $20^{\circ} \mathrm{C}$ higher. High temperatures increase the susceptibility of a support system to corrosion. Only mines 4 and 5 were characterised as acidic environments the rest of the mines described as weak alkaline or normal environments. The $\mathrm{pH}$ values of collected water samples varied from 3.4 to 8.0 and oxygen solubility ranged from 5.9 to $15.6 \mathrm{ppm}$.

The undertaken chemical analysis revealed a high concentration of aggressive ions such as $\mathrm{Cl}^{-}$and $\mathrm{SO}_{4}{ }^{-}$. Mine 1 is an example of high $\mathrm{Cl}^{-}$concentrations ranging from 1,938 to 5,701 ppm while the higher $\mathrm{SO}_{4}^{-}$ concentrations are associated with Mine 6 (2,737-18,053 ppm) and Mine \#4 (19,029-45,757 ppm). Aggressive ions in a solution attack the thin protective film that forms on the surface of metals thus making the metal more susceptible to corrosion. Again the impact of selected ions on the corrosivity of an environment has to be interpreted with reference to the presence or absence of inhibitors such as $\mathrm{HCO}_{3}{ }^{-}$ and $\mathrm{Ca}^{+}$. 
Table 1 Analysis of water samples collected at several mines

\begin{tabular}{|c|c|c|c|c|c|c|c|c|c|c|c|}
\hline \multirow[b]{2}{*}{ Parameter } & \multirow[b]{2}{*}{ Units } & \multicolumn{5}{|c|}{ Mine 1} & \multicolumn{3}{|c|}{ Mine 2} & \multicolumn{2}{|c|}{ Mine 3} \\
\hline & & Site \#1 & Site \#2 & Site \#3 & Site \#4 & Site \#5 & Site \#1 & Site \#2 & Site \#3 & Site \#1 & Site \#2 \\
\hline $\mathrm{HCO}_{3}$ & $\mathrm{mg} / \mathrm{L}$ & 170 & 100 & NA & NA & NA & 230 & 130 & NA & 270 & 250 \\
\hline $\mathrm{Ca}$ & $\mathrm{mg} / \mathrm{L}$ & 145 & 245 & 296 & 151 & 470 & 218 & 65 & 1,370 & 62 & 61 \\
\hline $\mathrm{Cu}$ & $\mathrm{mg} / \mathrm{L}$ & - & - & - & - & - & - & - & - & - & - \\
\hline $\mathrm{Fe}$ & $\mathrm{mg} / \mathrm{L}$ & - & - & - & - & - & - & - & - & 1 & - \\
\hline K & $\mathrm{mg} / \mathrm{L}$ & 23 & 30 & 49 & 29 & 52 & 5 & 2 & 3 & 3 & 4 \\
\hline $\mathrm{Mg}$ & $\mathrm{mg} / \mathrm{L}$ & 56 & 104 & 97 & 49 & 149 & 19 & 7 & 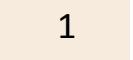 & 21 & 22 \\
\hline $\mathrm{Na}$ & $\mathrm{mg} / \mathrm{L}$ & 851 & 910 & 2,020 & 1,010 & 3,070 & 65 & 4 & 425 & 13 & 12 \\
\hline $\mathrm{Zn}$ & $\mathrm{mg} / \mathrm{L}$ & - & - & - & - & - & - & - & - & - & - \\
\hline $\mathrm{Cl}$ & $\mathrm{mg} / \mathrm{L}$ & 1,933 & 2,230 & 4,432 & 1,938 & 5,701 & 20 & 7 & 3,128 & 6 & 7 \\
\hline $\mathrm{NO}_{3}$ & $\mathrm{mg} / \mathrm{L}$ & NA & NA & 348 & 21 & - & 14 & ? & - & NA & NA \\
\hline $\mathrm{SO}_{4}{ }^{2-}$ & $\mathrm{mg} / \mathrm{L}$ & NA & NA & 78 & 182 & 247 & 452 & 32 & 733 & NA & 113 \\
\hline $\mathrm{pH}$ & & 7.3 & 7.1 & 7.8 & 8.0 & 7.7 & 7.0 & 7.1 & 6.9 & 7.3 & 7.5 \\
\hline Conductivity & $\mu S$ & 1,968 & 4,510 & 9,150 & 6,530 & 13,630 & 439 & 282 & 6,540 & 328 & 352 \\
\hline Salinity & ppt & 1.3 & 3.2 & 6.7 & - & 10.1 & 0.3 & 0.2 & 4.9 & 0.2 & 0.2 \\
\hline $\begin{array}{c}\text { Dissolved } \\
\text { oxygen }\end{array}$ & ppm & 9.0 & 12.7 & 7.4 & 8.8 & 8.7 & 7.3 & 11.1 & 5.9 & 13.0 & 15.6 \\
\hline \multirow[t]{2}{*}{ Temperature } & ${ }^{\circ} \mathrm{C}$ & 13.5 & 13.3 & 13.5 & 15.0 & 14.2 & 8.5 & 10.3 & 11.6 & 7.4 & 10.0 \\
\hline & & \multicolumn{4}{|c|}{ Mine 4} & \multicolumn{4}{|c|}{ Mine 5} & \multicolumn{2}{|c|}{ Mine 6} \\
\hline Parameter & Units & Site \#1 & Site \#2 & Site \#3 & Site \#4 & Site \#1 & Site \#2 & Site \#3 & Site \#4 & Site \#1 & Site \#2 \\
\hline $\mathrm{HCO}_{3}$ & $\mathrm{mg} / \mathrm{L}$ & 44 & 150 & NA & NA & 120 & - & NA & NA & NA & NA \\
\hline $\mathrm{Ca}$ & $\mathrm{mg} / \mathrm{L}$ & 278 & 295 & 404 & 449 & 585 & 336 & 424 & 381 & 290 & 182 \\
\hline $\mathrm{Cu}$ & $\mathrm{mg} / \mathrm{L}$ & - & - & 154 & 0 & - & - & 14 & - & - & - \\
\hline $\mathrm{Fe}$ & $\mathrm{mg} / \mathrm{L}$ & 90 & 57 & 589 & 33 & 106 & 675 & 334 & 2,170 & 1 & 0 \\
\hline $\mathrm{K}$ & $\mathrm{mg} / \mathrm{L}$ & 6 & 5 & 17 & 117 & 8 & 4 & 7 & 14 & 12 & 5 \\
\hline $\mathrm{Mg}$ & $\mathrm{mg} / \mathrm{L}$ & 56 & 55 & 591 & 187 & 154 & 106 & 380 & 446 & 46 & 29 \\
\hline $\mathrm{Na}$ & $\mathrm{mg} / \mathrm{L}$ & 57 & 43 & 821 & 859 & 113 & 9 & 132 & 63 & 416 & 136 \\
\hline $\mathrm{Zn}$ & $\mathrm{mg} / \mathrm{L}$ & 33 & 8 & 14,000 & 13,000 & 3 & 2 & 10 & 4 & 7 & 2 \\
\hline $\mathrm{Cl}$ & $\mathrm{mg} / \mathrm{L}$ & 78 & 80 & 368 & 789 & 10 & 19 & 50 & 140 & 1,450 & 49 \\
\hline $\mathrm{NO}_{3}$ & $\mathrm{mg} / \mathrm{L}$ & NA & NA & - & 1,696 & 6 & 519 & 93 & - & - & - \\
\hline $\mathrm{SO}_{4}$ & $\mathrm{mg} / \mathrm{L}$ & NA & NA & 45,757 & 19,029 & 88 & NA & 5,128 & 18,053 & 67 & 84 \\
\hline $\mathrm{pH}$ & & 5.7 & 6.4 & 3.4 & 4.4 & 5.9 & 3.3 & 2.9 & 4.0 & 7.2 & 7.1 \\
\hline Conductivity & $\mu S$ & 1,614 & 1,400 & 30,800 & 9,650 & 2,894 & 3,106 & 5,240 & 11,250 & 2,743 & 1,301 \\
\hline Salinity & ppt & 1.2 & 1.0 & 17.9 & 5.0 & 2.0 & 2.1 & 3.5 & 8.2 & 2.2 & 1.0 \\
\hline $\begin{array}{c}\text { Dissolved } \\
\text { oxygen }\end{array}$ & ppm & 12.8 & 12.3 & 6.5 & 7.4 & 11.8 & 12.9 & 8.0 & 8.8 & 11.2 & 9.3 \\
\hline Temperature & ${ }^{\circ} \mathrm{C}$ & 10.5 & 9.8 & 27 & 28.4 & 13.4 & 13.6 & 15.7 & 14.6 & 8.0 & 7.9 \\
\hline
\end{tabular}

Atmospheric corrosion is the natural degradation of material exposed to air and its pollutants. The rate of atmospheric corrosion is influenced by the relative humidity (the ratio of the quantity of water vapour present in the atmosphere to the saturation quantity at a given temperature). Corrosion rate increases beyond a critical humidity of over $60 \%$. Atmospheric corrosion is further accentuated by the presence of pollutants such as gas and particles. All these conditions are often present in underground mines. Furthermore, the ambient heat in deep mines also has a direct impact on the corrosion resistance of support systems. It is generally accepted that corrosion activity will double for each $10^{\circ} \mathrm{C}$ raise in temperature. 
Table 2 provides a summary of information collected during the mine site visits. Most mine sites were characterised by high relative humidity that contributes to corrosion.

Furthermore, the authors successfully used corrosion coupons to quantify corrosion rates under different mine conditions following ASTM G4 -01 and ASTM G1 -03 standards (Figure 2). Finally the loss of tensile strength as a function of corrosion rate was determined in the laboratory, Dorion et al. (2009, 2010).

\section{Table 2 Average atmospheric data at selected sites between July 2008 and January} 2009

\begin{tabular}{|c|c|c|c|c|c|c|c|c|c|}
\hline \multirow[b]{2}{*}{ Parameter } & \multicolumn{3}{|c|}{ Mine 1} & \multicolumn{3}{|c|}{ Mine 2} & \multicolumn{3}{|c|}{ Mine 3} \\
\hline & Site \#3 & Site \#4 & Site \#5 & Site \#1 & Site \#2 & Site \#3 & Site \#1 & Site \#2 & Site \#3 \\
\hline Temperature $\left({ }^{\circ} \mathrm{C}\right)$ & 15.4 & 14.5 & 16.7 & 12.3 & 12.2 & 12.5 & 15.1 & 11.5 & 11.7 \\
\hline Relative humidity (\%) & 68 & 58 & 73 & $>85$ & 85 & $>80$ & 68 & 69 & 76 \\
\hline Condensation & Weak & Weak & Dry & Wet & Weak & Wet & Splashing & Dry & Dry \\
\hline Dust & Weak & No & Strong & No & No & No & Yes & No & Yes \\
\hline Gas & No & No & Yes & No & No & Weak & Yes & No & Yes \\
\hline Air flow (cfm) & 45,000 & 132,500 & 47,000 & 0 & 42,000 & 0 & 88,000 & 52,000 & 262,000 \\
\hline \multirow[t]{2}{*}{ Air quality } & Fresh & Fresh & Operation & Stagnant & Fresh & Stagnant & $70 \%$ recycled & Fresh & Exhaust \\
\hline & \multicolumn{3}{|c|}{ Mine 4} & \multicolumn{3}{|c|}{ Mine 5} & & & \\
\hline Parameters & Site \#1 & Site \#2 & Site \#3 & Site \#1 & Site \#2 & Site \#3 & & & \\
\hline Temperature $\left({ }^{\circ} \mathrm{C}\right)$ & 13.3 & 14.1 & 29.3 & 13.0 & 13.6 & 16.9 & & & \\
\hline Relative humidity (\%) & 96 & 96 & 79 & 90 & 90 & 81 & & & \\
\hline Condensation & Wet & Wet & Dry & Wet & Wet & Weak & & & \\
\hline Dust & No & No & Yes & No & No & No & & & \\
\hline Gas & Yes & Yes & Yes & Yes & Yes & No & & & \\
\hline Air flow (cfm) & 120,950 & 80,400 & 34,000 & 330,000 & 33,000 & 0 & & & \\
\hline Air quality & Exhaust & Exhaust & Exhaust & Exhaust & Exhaust & Stagnant & & & \\
\hline
\end{tabular}

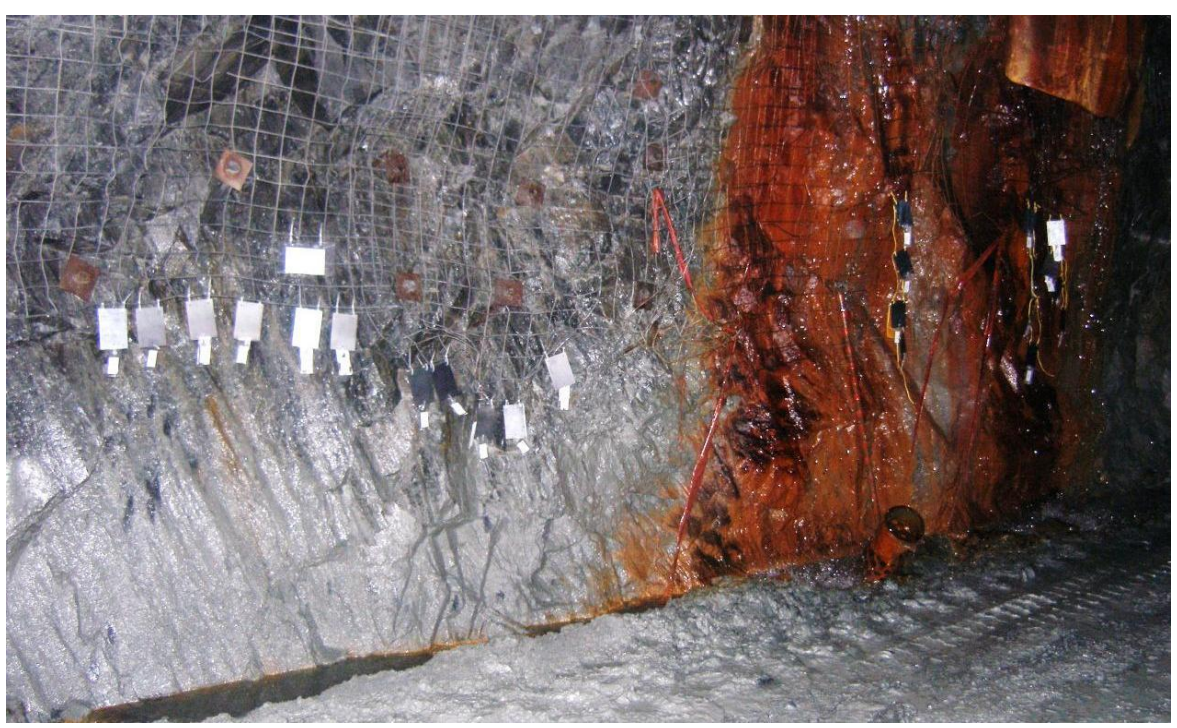

\section{Figure 2 Corrosion coupons attached to the mine screen on the drift wall, exposed to atmospheric and aqueous conditions}

Collected corroded rock reinforcement and support elements were brought to the laboratory to determine the capacity of corroded mesh, plate and friction bolts. These were complemented by microphotography to identify the type of corrosion on collected sample (Figure 3) and X-ray diffraction to determine the most abundant mineral species in the corrosion products. Microscopic observations helped identify the main corrosion forms and provided an insight on the impact of rock and mineral particles on corrosion of the 
steel support. (S.E.M.) was used to identify and compare forms of corrosion and corrosion products observed at the collected rock support units (Figure 4).

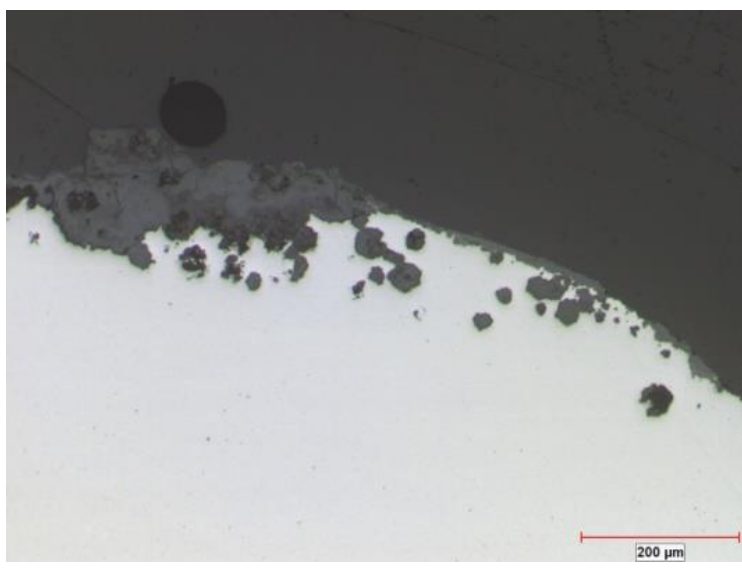

a)

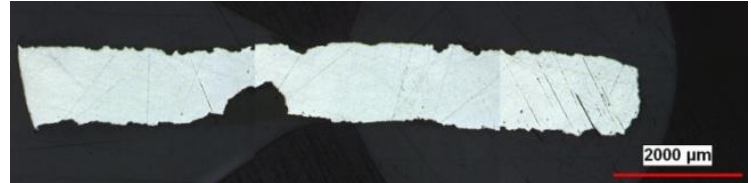

b)

Figure 3 a) Microphotography of mesh subject to pitting corrosion; b) Microphotography of a piece of a corrosion coupon exposed to atmospheric condition with non-uniform and pitting corrosion

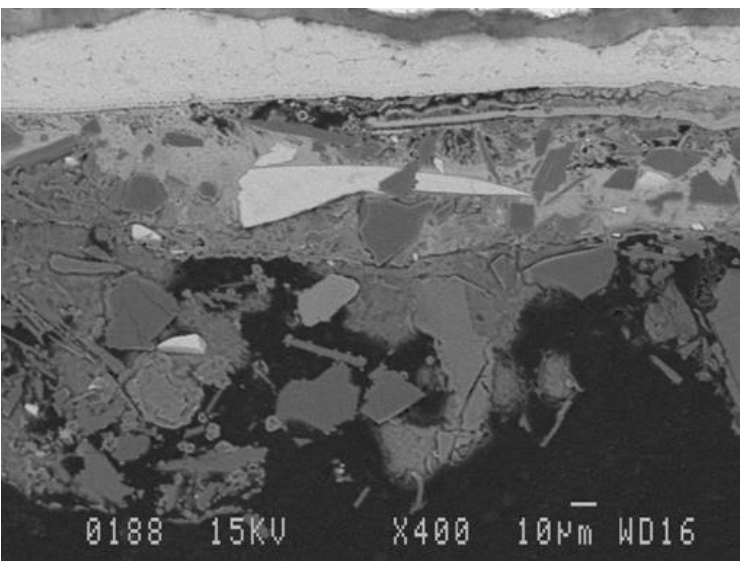

a)

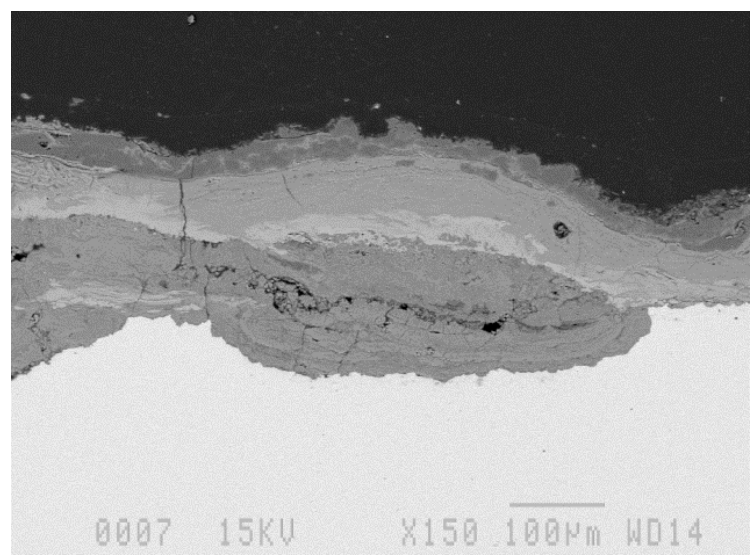

b)

Figure 4 a) S.E.M. photography of a plate corrosion crust containing many different minerals particles; b) S.E.M. photography of a corrosion coupon exposed to atmospheric corrosion

\section{$3 \quad$ Interpreting in situ observations and laboratory investigations}

For practical purposes it is useful to be able to link in situ observations of corrosion on support to estimates of corrosion rates. Table 3 provides a series of recommendations linking on site observations on the level of corrosion to resulting corrosion rate and loss of capacity. Furthermore, it makes suggestions on the need for required intervention that may involve replacing of corroded units or rehabilitation.

Although aqueous corrosion is often attributed to low pH other factors come to play. For example, concentrations of dissolved oxygen in water were seen to contribute to corrosion in underground mines, Hassell et al. (2004). During the present investigation corrosion coupons were installed under a range of aqueous conditions. It was observed that conductivity was the controlling factor for water with $\mathrm{pH}$ between 5 and 8. The influence of iron bacteria is also important as with coupons installed for 12 months in water with iron bacteria showing high corrosion rates. Solid mineral deposits on the reinforcement and support steel create a barrier and result in lower corrosion rates over time. The corrosion rate of steel as a function 
of water conductivity is illustrated in Figure 5. This applicability of this graph is for water of pH between of 6 to 8 and conductivity under $6,000 \mu \mathrm{S}$.

\section{Table 3 Linking on site observations to resulting loss of capacity and required} intervention

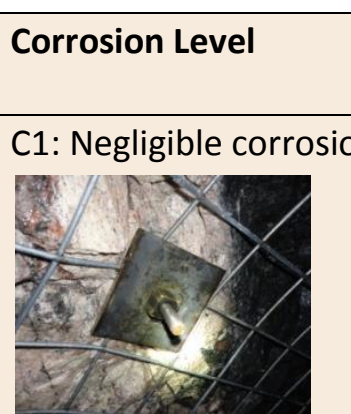

C2: Localised corrosion

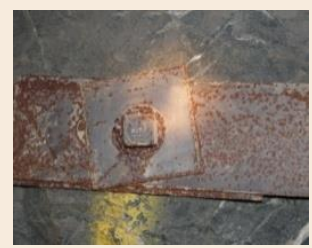

C3: Surface corrosion

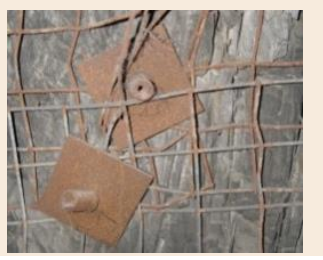

C4: Advanced corrosion

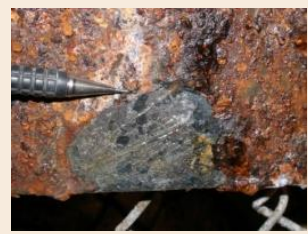

C5: Very advanced corrosion

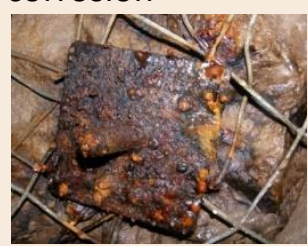

C6: Extreme corrosion

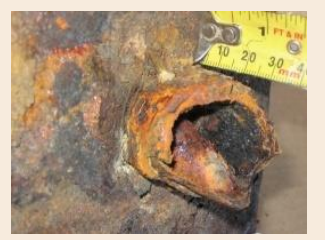

Description

0.02 to

$0.04 \mathrm{~mm} / \mathrm{yr}$

10 to

$20 \%$

4.50 to

None

characterised by

localised spots on the

surface.

Between 10 and $75 \%$ of the surface is corroded.

Steel is in good

condition.

Corrosion over $75 \%$ of the surface. Corrosion is only on surface. If a corrosion crust is present it is very thin. Can identify blisters.

$100 \%$ of the surface is corroded.

0.15 to

0.04 to

20 to

4.00 to

None to follow

$0.15 \mathrm{~mm} / \mathrm{yr}$ $35 \%$

$4.50 \mathrm{~mm}$ up.

$0.30 \mathrm{~mm} / \mathrm{yr} \quad 50 \% \quad 4.50 \mathrm{~mm}$ installed over

Can identify blisters.

Thin corrosion crust

$(<1 \mathrm{~mm})$ easily removed.

12 months it

will display

signs of severe corrosion.

$100 \%$ of the surface is

0.30 to

50 to

2.50 to

Consider

corroded.

$0.60 \mathrm{~mm} / \mathrm{yr}$

$75 \%$

$3.50 \mathrm{~mm}$

replacement of

Thick corrosion crust

installed units.

$(>1 \mathrm{~mm})$ and flaky.

Corrosion goes through the steel.

$>0.50 \mathrm{~mm} / \mathrm{yr} \quad>75 \%$

$<2.50 \mathrm{~mm}$ Reconditioning. May require immediate Integrity of steel has been damaged. intervention. breakable by hand. 


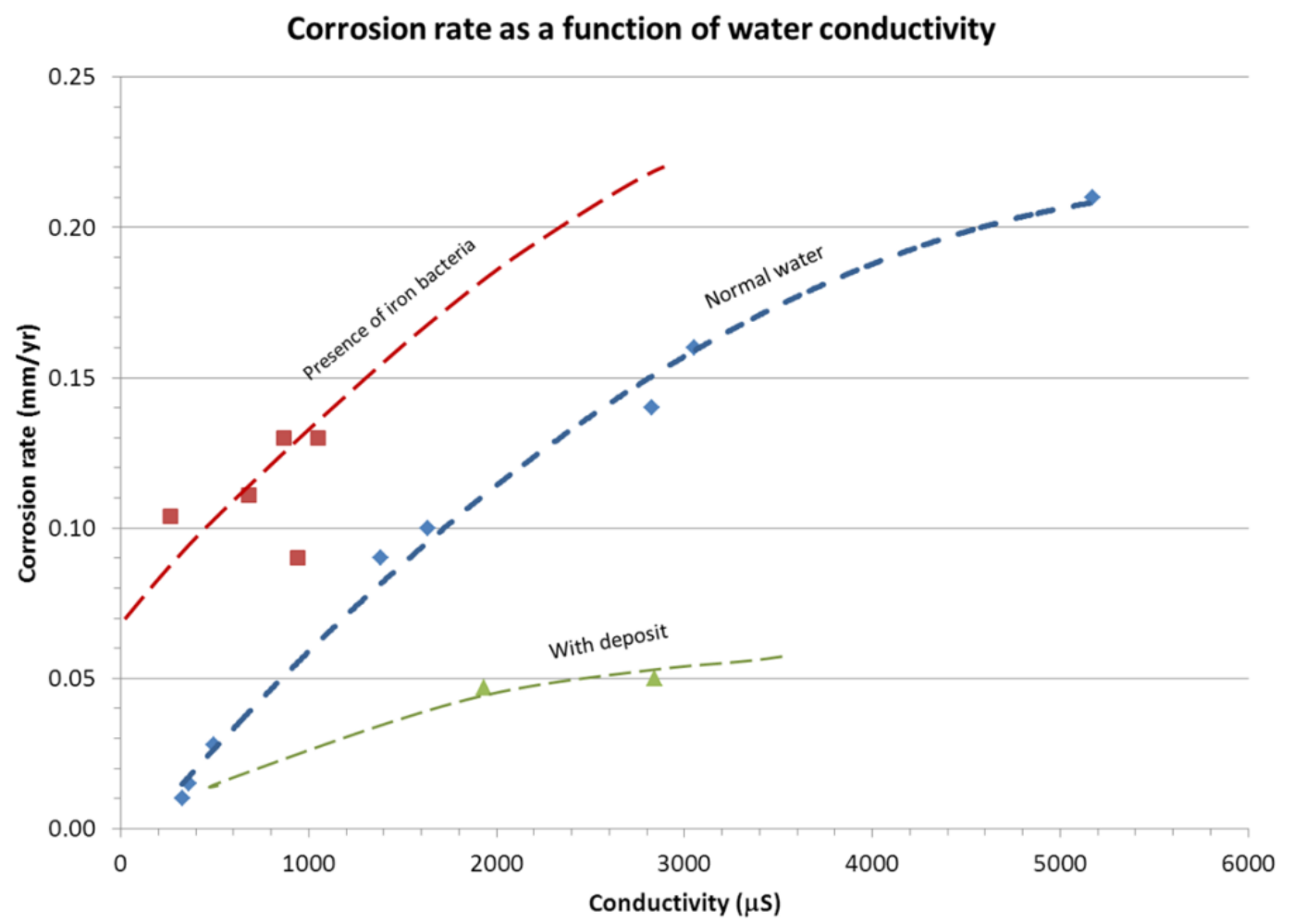

Figure 5 Determining corrosion rate as a function the conductivity of the water to $\mathrm{pH} 6$ to 8

\section{$4 \quad$ Loss of capacity due to corrosion}

\subsection{Loss of capacity of reinforcement elements}

The loss of capacity of bolts exposed to 'low to moderate corrosion conditions' and to 'moderate to high corrosion conditions' has been demonstrated by pull out tests on Swellex bolts as reported by Charette et al. (2004) and Charette (2012). Villaescusa et al. (2008), simulating conditions in Australian hard rock mines, suggested service life estimates for cable strand in strong groundwater flow environments. In our work we have addressed the loss of capacity of friction bolts by extrapolating from work in corrosion chambers, laboratory testing and on site observations.

\subsection{Loss of capacity of \#6 mesh}

During this project more than 60 samples of \#6 mesh screen, displaying a range of corrosion levels, were tested in tension (ASTM E8-99). Results were compared with non-corroded samples and results from Villaescusa (2004). Prior to conducting measurements of the diameter of the strands of wire, the corrosion crust was peeled off using a scraper and steel wool and the minimum diameter of the strands (in $\mathrm{mm}$ ) was measured using a calliper. It was thus possible to determine the residual tensile strength of the wire, or the loss in strength, since installation. The relationship between the break capacity and the diameter of the wire strands, and the correlation between percentage of residual capacity of wires \# 6 and their diameter were estimated as:

$$
\text { \#6 mesh capacity }(\mathrm{kN})=0.38 \mathrm{D}^{2.2}
$$

Residual capacity of \#6 mesh (\%) $=2.8 D^{2.2}$

Where:

D $=$ diameter in $\mathrm{mm}$. 
For design purposes it is possible to use Figures 7 and 8 showing the curve obtained using the above relationships and levels of corrosion. This provides a link to the onsite observations described in Table 3.

\section{Capacity of \#6 mesh as function of strand diameter}

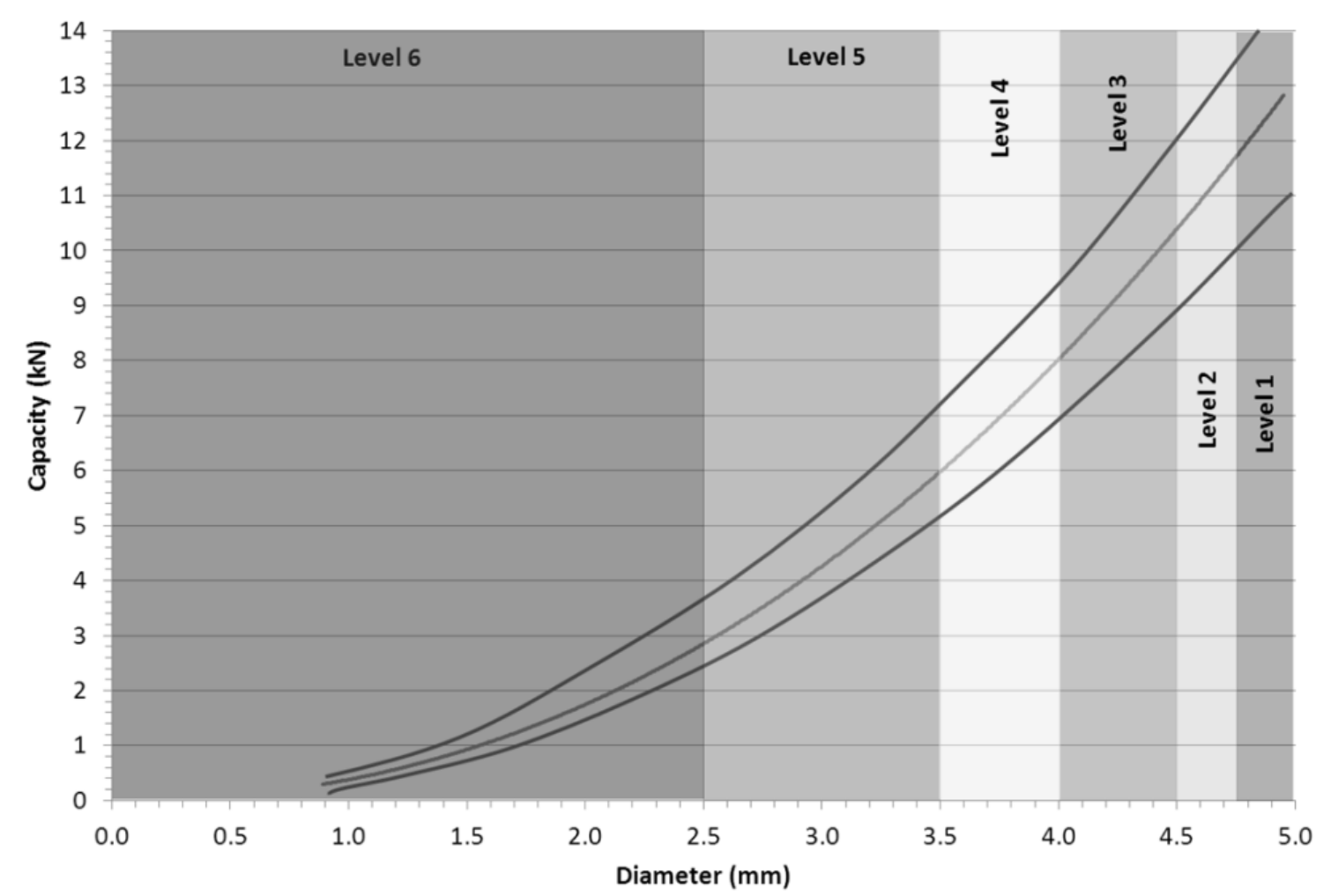

Figure 6 Theoretical relationship between the breaking force and the diameter of wire strand 


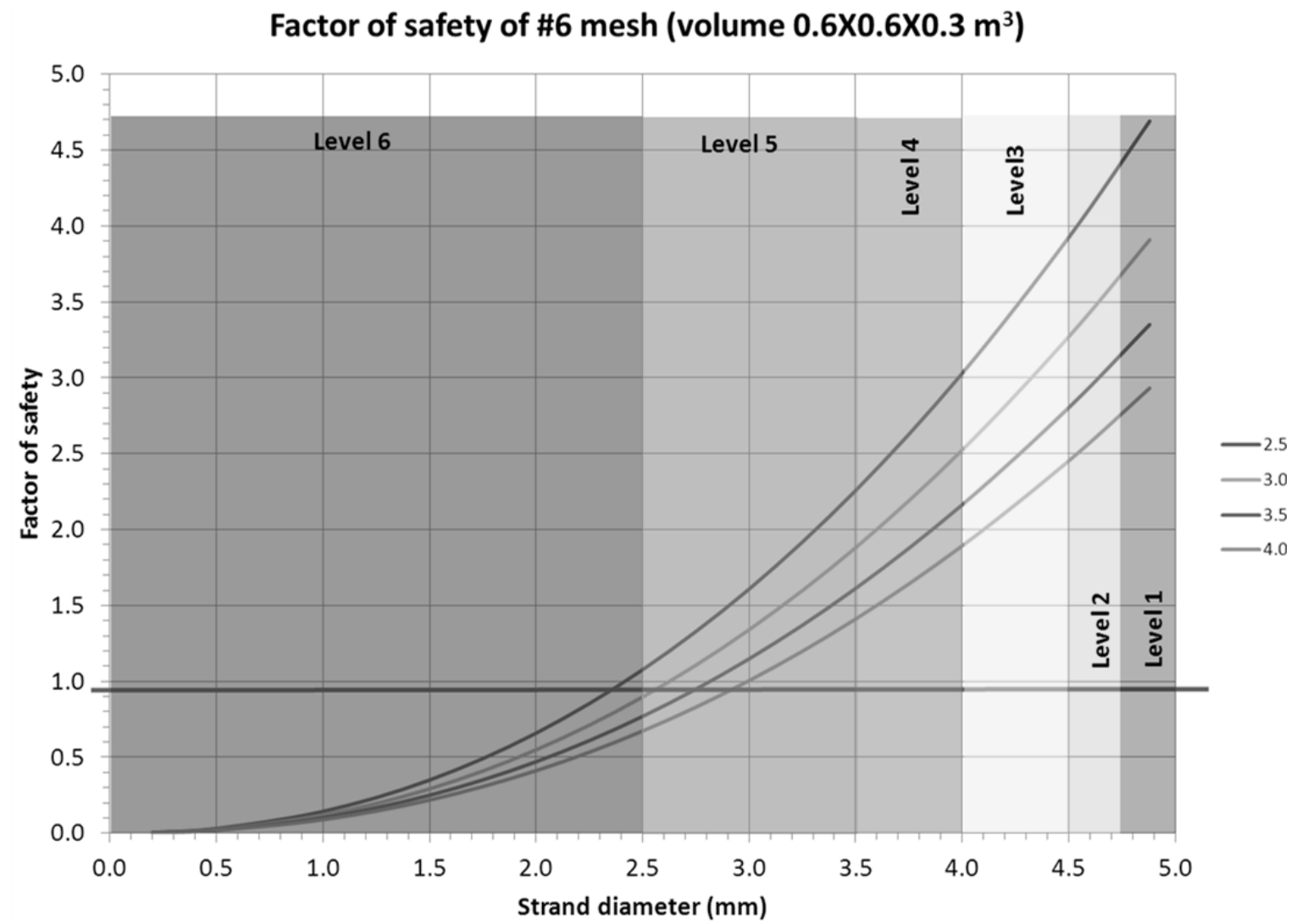

Figure 7 Relationship between the residual capacity of the strands and their diameter (Numbers refer to factor of safety)

A first approximation of the residual capacity can be estimated, under different corrosion rates, based on the time of exposure. For example, for an initial diameter of \#6 mesh of $4.88 \mathrm{~mm}$ exposed to a corrosion environment that is characterised by a corrosion rate of $0.05 \mathrm{~mm} /$ year. Based on the design chart in Figure 7, the loss in mesh capacity after 2 years of exposure ( 2 years $\times 0.05 \mathrm{~mm} / \mathrm{year}$ ) and assuming a constant corrosion environment, the mesh diameter will be reduced to $4.78 \mathrm{~mm}$.

$$
\text { Residual capacity }(\%)=2.8 \times D^{2.2}=2.8 \times(4.78)^{2.2}=87 \%
$$

If the mesh is exposed for 20 years:

$$
2.8 \times D^{2.2}=2.8 \times(4.88-(0.05 * 20))^{2.2}=55 \%
$$




\section{Residual capacity of \#6 Mesh as function of corrosion rate}

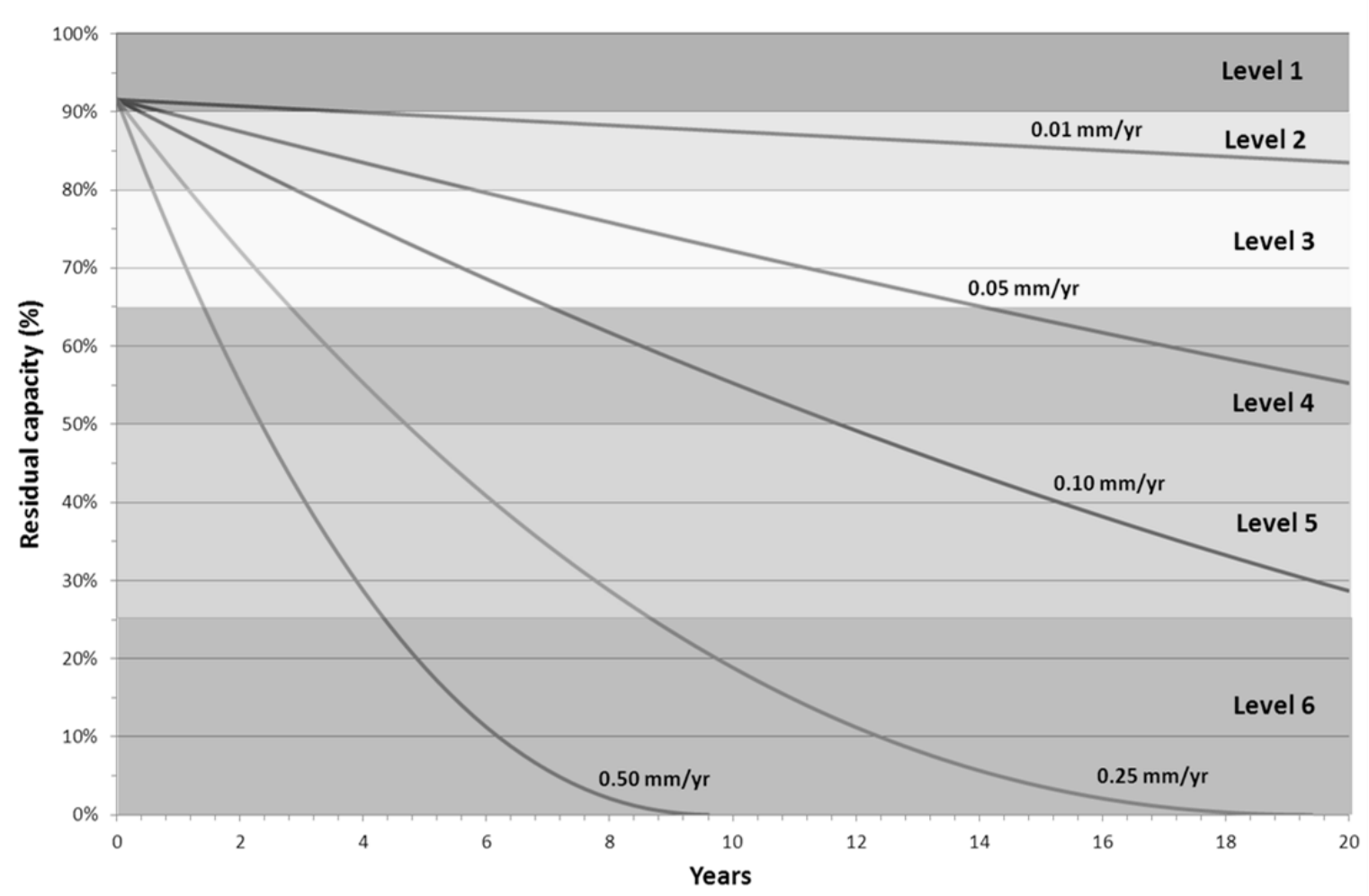

Figure 8 Residual capacity of the mesh \#6 in function of time for various corrosion rates

\section{$5 \quad$ Selection and design of support systems accounting for corrosion}

There are several guidelines for the selection and design of support systems. Quite often mine operators rely on experience, or the use of empirical and analytical tools. A common limitation of most approaches is that they do not seem to account for the potential impact of corrosion on the longevity of a reinforcement or support element. Table 4, based on the in situ and laboratory investigations of the authors, aims to provide a tool to alert mine operators on the susceptibility of reinforcement and support elements to corrosion. It is recognised that failure of any element can result in failure of the support system.

The flowcharts in Figures 10 and 11 provide a pathway to characterise the corrosivity of different mining environments, and guide the planning and conduct surveillance (monitoring) of support in place. These charts should be used with classification charts of aqueous and atmospheric corrosion and with respect of support susceptibility guide for assessing corrosion. 
Table 4 Susceptibility of support systems to corrosion

\begin{tabular}{|c|c|c|c|}
\hline $\begin{array}{l}\text { Support } \\
\text { Category }\end{array}$ & Support Element & $\begin{array}{l}\text { Corrosion } \\
\text { Susceptibility }\end{array}$ & Justification \\
\hline Reinforcement & $\begin{array}{l}\text { Friction bolts (Split Set) } \\
\text { Swelling bolts (Swellex) }\end{array}$ & High & $\begin{array}{l}\text { Hollow bolts with low thickness steel. } \\
\text { Decrease in thickness of bolt can result in } \\
\text { large loss of capacity. Borehole conditions } \\
\text { susceptible to exposure to water. Contact } \\
\text { with rock or sulphides. }\end{array}$ \\
\hline $\begin{array}{l}\text { Surface } \\
\text { support }\end{array}$ & $\begin{array}{l}\text { Mesh } \\
\text { Push-plate }\end{array}$ & High & $\begin{array}{l}\text { Strands of thin mesh are exposed over large } \\
\text { areas. Push plate thickness is thin. }\end{array}$ \\
\hline Reinforcement & $\begin{array}{l}\text { Rockbolts } \\
\text { Bolt nuts } \\
\text { Eye-bolt, J-bolt }\end{array}$ & Medium & $\begin{array}{l}\text { Bolt rods are solid and have a relatively thick } \\
\text { diameter. }\end{array}$ \\
\hline $\begin{array}{l}\text { Surface } \\
\text { support }\end{array}$ & $\begin{array}{l}\text { Plates } \\
\text { Straps }\end{array}$ & Medium & Plate thickness is greater. \\
\hline Reinforcement & $\begin{array}{l}\text { Reinforcement elements } \\
\text { that have been treated } \\
\text { (galvanised, } \mathrm{Mn} \text {, etc.) }\end{array}$ & $\begin{array}{l}\text { Medium to } \\
\text { low }\end{array}$ & $\begin{array}{l}\text { Corrosion attack delayed by protection and } \\
\text { use of inhibitors. In some corrosive } \\
\text { environments, galvanisation can offer long } \\
\text { term protection. Thickness of bolts is } \\
\text { important. }\end{array}$ \\
\hline $\begin{array}{l}\text { Surface } \\
\text { support }\end{array}$ & $\begin{array}{l}\text { Support elements that } \\
\text { have been treated } \\
\text { (galvanised, Mn, etc.) }\end{array}$ & $\begin{array}{l}\text { Medium to } \\
\text { low }\end{array}$ & $\begin{array}{l}\text { Attack delayed by protection and inhibitors. } \\
\text { In some corrosive environments, galvanised } \\
\text { support protects for the long term. Plate } \\
\text { thickness is an important factor. }\end{array}$ \\
\hline Reinforcement & $\begin{array}{l}\text { Resin rebar or grout } \\
\text { rebar } \\
\text { Grout cable }\end{array}$ & Low & $\begin{array}{l}\text { Protection from environment (air, water). } \\
\text { Corrosion localised and/or stress cracking } \\
\text { corrosion if the resin or cement is cracked. }\end{array}$ \\
\hline $\begin{array}{l}\text { Surface } \\
\text { support }\end{array}$ & $\begin{array}{l}\text { Support installed under } \\
\text { shotcrete }\end{array}$ & Low & $\begin{array}{l}\text { Protection from environment (air, water). } \\
\text { Corrosion localised and/or stress cracking. } \\
\text { Corrosion if the resin or cement is cracked. }\end{array}$ \\
\hline
\end{tabular}

There are several tools that can be used to characterise the corrosivity of a mining environment exposed to aqueous and atmospheric conditions. As the field studies demonstrated, a number of variables can result in aggressive corrosive environments for rock support systems. The use of the analytical tests in conjunction with the corrosivity classification can provide a design tool and can allow the reporting of corrosion in a consistent matter by those responsible for quality control of rock support systems. It furthermore provides a tool to monitor the evolution of support system corrosion support over time and allow time for prompt intervention as required. 


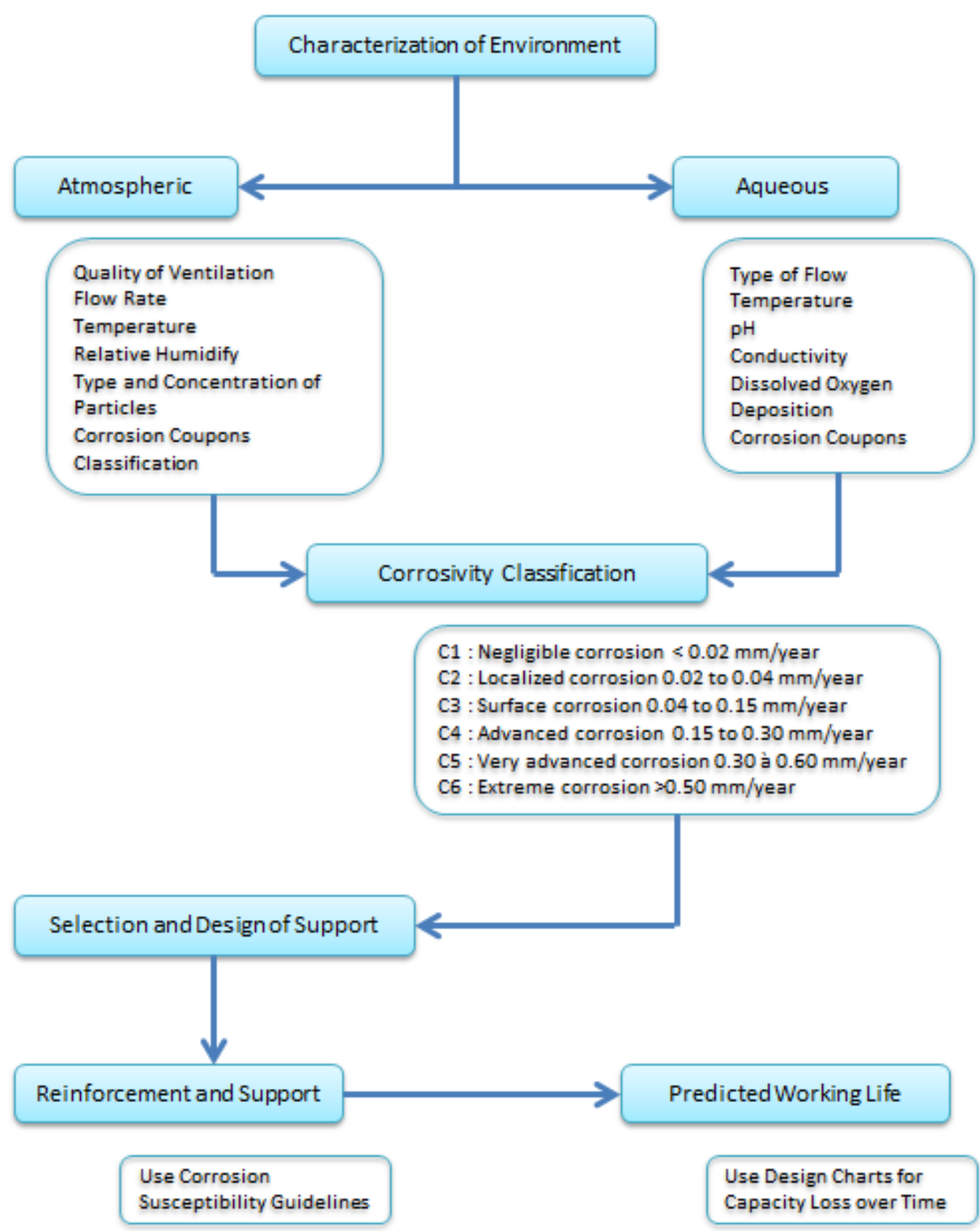

\section{Figure 9 Design methodology for corrosivity classification and selecting of reinforcement and support}

This process does not replace the geomechanical design guidelines for the selection of support systems. Rather it complements the selection and design process as it identifies the implications of using a particular reinforcement or surface support element in a corrosive environment. As such it can be useful in any tradeoff study that has to account for geomechanical, corrosion, economic and production considerations in the choice of a support system. 


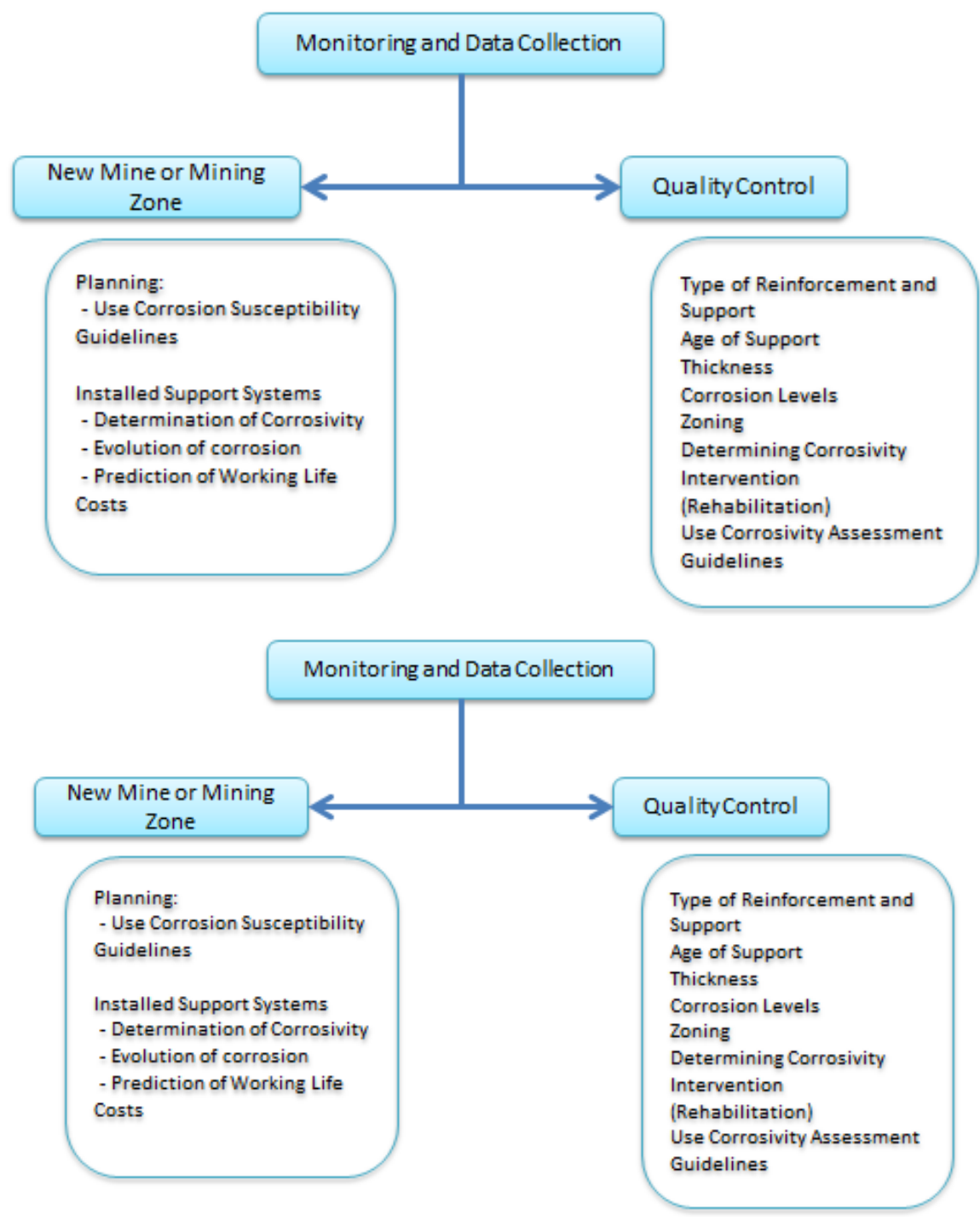

\section{Figure 10 Use of monitoring data for decision making}

\section{Conclusions}

The corrosion of support systems has significant economic and safety consequences for operating mines. A better understanding of the conditions that control the corrosion rate of support systems can be used to predict how long it will take for the support capacity to be reduced based on the mineralogy of an orebody. This in turn can be used by mine operators in mine planning, to improve strategies for choosing support. For instance, different support materials may be used depending upon whether an area is for short or long term access. In addition, it can be used to identify areas that may need reconditioning of support.

It has been demonstrated that corrosion coupons provide an excellent method to quantify the corrosion rate of support in an underground mining environment. Coupons installed at different sites provided a consistent narrative on the evolution of corrosion of support in a range of environments. The implementation of a tensile test program demonstrated the direct relationship between the tensile strength of corroded samples and the recorded corrosion rate, or thickness, of the component. This has allowed the construction of a design chart to quantify the impact of corrosion on the loss of capacity of rock support. A review of on-site observations over a five year period and from the experimental program has allowed the authors to prepare a series of guidelines on the susceptibility of different support elements. This can provide an additional design tool to identify the optimum support strategy for a given mining operation. 


\section{Acknowledgement}

The authors acknowledge the continued support of the management and on-site personnel of the following mine sites: LaRonde, Mouska, Doyon-Weswood, Niobec, Persévérance and Géant-Dormant. The authors further acknowledge the technical support provided by Vicky Dodier, Daniel Marcotte, Geneviève Bruneau, Maude Larouche, Jean Frenette and Marie-Josée Bouchard.

\section{References}

ASTM Standard, Designation: G4-01 (2003), Standard Guide for Conducting Corrosion Tests in Field Applications, ASTM International, 100 Barr Harbor Drive, PO Box C700, West Conshohocken, PA 19428-2959, United States.

ASTM Standard, Designation: G1-03 (2001), Standard Practice for Preparing, Cleaning, and Evaluating Corrosion Test Specimens, ASTM International, 100 Barr Harbor Drive, PO Box C700, West Conshohocken, PA 19428-2959, United States.

ASTM Standard, Designation: E8- 99 (1999), Standard Test Methods to Tension Testing of Metallic Materials, ASTM International, 100 Barr Harbor Drive, PO Box C700, West Conshohocken, PA 19428-2959, United States.

Charette, F. (2012) Stochastic Approach to the Corrosion Assessment of Rock Bolts, ROCKENG12, in Proceedings 21st Canadian Rock Mechanics Symposium, May 5-9 2012, Edmonton, CARMA, pp. 303-310.

Charette, F., Germain, P. and Hadjigeorgiou, J. (2004) Corrosion Behaviour of Swellex Bolts in Underground Mining Environments, Canadian Institute of Mining, Annual General Meeting, Edmonton.

Dorion, J.F., Hadjigeorgiou, J. and Ghali, E. (2010) Influence of corrosion rate on the capacity of rock support, ARMA 10-259, American Rock Mechanics Association, in Proceedings 44th US Rock Mechanics Symposium and 5th U.S.-Canada Rock Mechanics Symposium, 27-30 June 2010, Salt Lake City, UT.

Dorion, J.F., Hadjigeorgiou, J. and Ghali, E. (2009) Quantifying the rate of corrosion in selected underground mines, in Proceedings Rock Eng09, May 9-14 2009, Toronto, CARMA.

Dorion, J.F. and Hadjigeorgiou, J. (2008) Caractérisation des environnements miniers menant à la corrosion des systèmes de soutènement, in Proceedings Maintenance Engineering Underground Mine Operators Conference, CIM, Val D’Or, CD-rom only.

Hadjigeorgiou, J. Dorion, J.F. and Ghali, E. (2008) Support System Performance Under Different Corrosion Conditions, The Journal of the Southern African Institute of Mining and Metallurgy, Vol. 108 June 2008, pp. 359-365.

Hadjigeorgiou, J., Ghali, E., Charette, F. and Krishnadev, M.R. (2002) Fracture analysis of friction rock bolts, in Proceedings 5th North American Rock Mechanics Symposium and the 17th Tunnelling Association of Canada, Conference: NARMS-TAC, 7-10 July 2002, University of Toronto Press, pp. 881-887.

Hassell, R., Villaescusa, E., Thompson, A.G. and Kinsella, B. (2004) Corrosion assessment of ground support systems, in Proceedings Fifth International Symposium on Ground Support, Ground Support in Mining and Underground Construction, E. Villaescusa and Y. Potvin (eds), 28-30 September 2004, Perth, Australia, Balkema, Rotterdam, pp. 529-542.

Li., C. and Lindblad, K. (1999) Corrosion classification of the underground environment, Rock Support and Reinforcement Practice in Mining, E. Villaescusa, C.R. Windsor and A.G. Thompson (eds), Balkema, Rotterdam, pp. 69-75.

Robinson, J. and Tyler, D.B. (1999) A study of corrosion in underground reinforcement at Mount Isa Mines, Corrosion classification of the underground environment, Rock Support and Reinforcement Practice in mining, E. Villaescusa, C.R. Windsor, and A.G. Thompson (eds), Balkema, Rotterdam, pp. 77-82.

Villaescusa, E., Hassell, R. and Thompson, A.G. (2008) Development of a corrosivity classification for cement grouted cable strand in underground hard-rock mining excavations, The Journal of the Southern African Institute of Mining and Metallurgy, Vol. 108 June 2008, pp. 301-308.

Villaescusa, E. (2004) Weld Mesh for static rock support in Australia, in Surface Support in Mining, Y. Potvin, T.R. Stacey and J. Hadjigeorgiou (eds), Australian Centre for Geomechanics, Perth, pp. 385-389. 
Corrosion 